\title{
Mechanical and physical properties of metakaolin based geopolymer paste
}

\author{
Puput Risdanareni ${ }^{1}$, Poppy Puspitasari ${ }^{2}$, Edi Santoso $^{1}$, Edo Prasetya Adi ${ }^{1}$ \\ ${ }^{1}$ Civil Engineering Department, Engineering Faculty, Universitas Negeri Malang, Malang, Indonesia \\ ${ }^{2}$ Mechanical Engineering Department, Engineering Faculty, Universitas Negeri Malang, Malang, Indonesia
}

\begin{abstract}
This paper presents the result of studies on utilizing metakaolin obtained from Belitung as fly ash substitute material to produce geopolymer paste. Mechanical properties were assessed by compressive strength while physical properties were assessed by setting time, porosity, microstructure test and density test. The experiment was performed on geopolymer paste with $0,25 \%, 50 \%, 75 \%$ and $100 \%$ fly ash replacement with metakaolin. Sodium Hidroxide $(\mathrm{NaOH})$ with concentration of 10 Molars and Sodium Silicate $(\mathrm{Na} 2 \mathrm{SiO} 3)$ were used as alkaline activator. In addition, activator ratio between sodium silicate to sodium hidroxide of 2 was applied. The result obtains that increasing metakaolin contain in mixture deliver longer setting time, higher open pore number, lower density and lower compressive strength of geopolymer paste. However, adding metakaolin up to $25 \%$ into geopolymer paste mixture could increase mechanical and physical properties of geopolymer paste.
\end{abstract}

\section{Introduction}

Recently, research on investigating alternative material as cement substitute becomes a massive issue in construction industry. Previous research proved that utilizing cement contribute bad environment effect due to high $\mathrm{CO}_{2}$ emitted during its production $[1,2]$. Hence, reducing cement use by replacing or substituting it with other eco green material will be an enable solution for a better future.

Geopolymer material, a new eco green material synthesized from precursor and alkaline activator revealed as a promising construction material to reduce utilization of Portland cement [3]. Precursor which has high silica and alumina content is required to produce geopolymer binder. Fly ash, a waste material derived from coal combustion process which rich in silica and alumina become a popular precursor in producing geopolymer binder [4]. Hence, sodium hydroxide $(\mathrm{NaOH})$ and sodium silicate $\left(\mathrm{Na}_{2} \mathrm{SiO}_{3}\right)$ are used as alkaline activator.

As a waste material, controlling and predicting quality of geopolymer binder produced from fly ash became a though jobs [5]. Therefore, utilizing alternative precursor materials besides fly ash that has stable properties are required in producing geopolymer binder.

Metakaolin, a material produced from kaolin calcinations which has similar content to fly ash was considering as alternative precursor material besides fly ash. Based on statistic data from ministry of energy and mining resources of Indonesia in 2010, availability of Kaolin in Indonesia is abundant and less utilization. Hence, in this study metakaolin (MK) was used as precursor replacing fly ash (FA) to produce geopolymer

\footnotetext{
* Corresponding author: puput.risdanareni.ft@um.ac.id
}

paste. In order to find optimum doses of metakaolin as fly ash replacing, five metakaolin doses variation of $0 \%$, $25 \%, 50 \%, 75 \%$ and $100 \%$ was performed.

Previous research stated that concentration of $\mathrm{NaOH}$ and ratio between $\mathrm{NaOH}$ and $\mathrm{Na}_{2} \mathrm{SiO}_{3}$ played important role in developing mechanical and physical properties of geopolymer paste [4]. Based on previous study by Ekaputri, $\mathrm{NaOH}$ concentration of 10 molars and alkaline activator ratio of 2 was used in this research due to its good performance previously [6].

In general, investigating mechanical properties and physical properties of geopolymer paste which produced from metakaolin and fly ash become the first aim of this research. Giving recommendation of optimum composition of metakaolin as fly ash replacement is the second aim of this study.

\section{Material and method}

\subsection{Materials}

Fly ash class $\mathrm{C}$ obtained from PT. Petrokimia gresik and kaolin class $\mathrm{N}$ from Belitung Island with density of 2.47 $\mathrm{gr} / \mathrm{cm}^{3}$ and $2.36 \mathrm{gr} / \mathrm{cm}^{3}$ was used as raw material. Kaolin was calcined in temperature of $700^{\circ}$ Celcius in order to perform metakolin. Both metakaolin (MK) and fly ash (FA) was sieved and passes sieve number 200. Chemical composition of fly ash and metakaolin obtained from XRF test was presented at Table 1.

A clear gel of $\mathrm{Na}_{2} \mathrm{SiO}_{3}$ and a flake shape of $\mathrm{NaOH}$ were used as alkaline activator. $\mathrm{NaOH}$ solution with concentration of 10 molars and activator ratio between 
$\mathrm{Na}_{2} \mathrm{SiO}_{3}$ and $\mathrm{NaOH}$ of 2 was performed in this research. $\mathrm{NaOH}$ solution was prepared by dissolving $\mathrm{NaOH}$ flake into distilled water one day prior before it use.

Table 1. Chemical composition of fly ash and metakaolin

\begin{tabular}{|c|c|c|}
\hline Particles & FA \% by mass & MK \% by mass \\
\hline $\mathrm{SiO}_{2}$ & 35.91 & 31 \\
\hline $\mathrm{Al}_{2} \mathrm{O}_{3}$ & 16.02 & 53.5 \\
\hline $\mathrm{CaO}$ & 14.43 & 1.1 \\
\hline $\mathrm{Fe}_{2} \mathrm{O}_{3}$ & 12.34 & 6.58 \\
\hline $\mathrm{K}_{2} \mathrm{O}$ & 1.28 & 5.79 \\
\hline $\mathrm{MgO}$ & 9.09 & 0.12 \\
\hline $\mathrm{Na}_{2} \mathrm{O}$ & 5.87 & 0.04 \\
\hline $\mathrm{TiO}_{2}$ & 0.66 & 0.919 \\
\hline
\end{tabular}

\subsection{Method}

Flow chart diagram for this research was ilustrated at figure 1. Preparing material such as fly ash, metakaolin, and alkaline activator was conducted at first stage of this research. Next step was perform preliminary material test such as XRF, XRD and SEM. Consistency normal and setting time was conducted in order to investigate physical propertis of fresh geopolymer paste. After manufacturing paste and cure paste at room temperature, paste speciment was tested for its density, compressive strength and pororosity. Last stage of this research is performed data analysis for all testing.

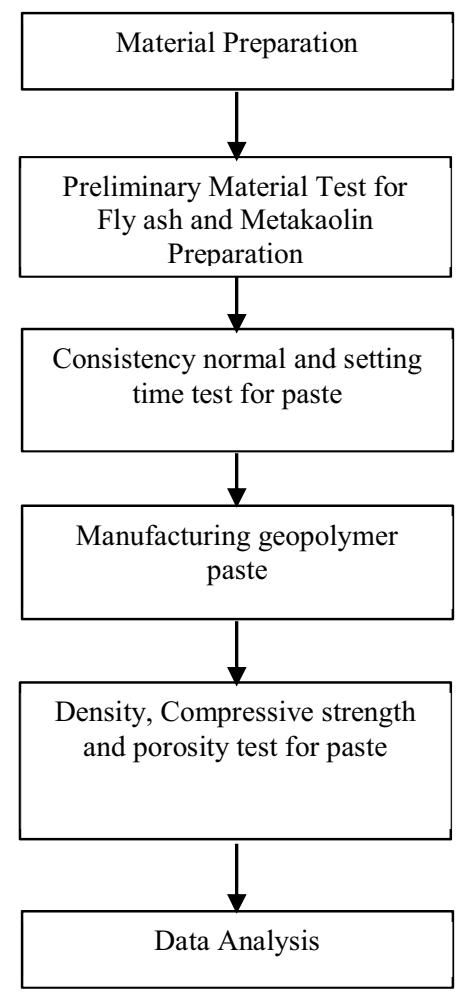

Fig. 1. Experimental Flow Chart Diagram

\subsection{Specimens and mixture proportions}

Specimens of geopolymer paste were cylinder with the diameter of $2 \mathrm{~cm}$ and the height of $4 \mathrm{~cm}$. Five mixture proportions of $0 \%, 25 \%, 50 \%, 75 \%$ and $100 \%$ based on metakaolin content was produced in this study. Ratio between alkaline activator and precursor used in this research was 0.6. Table 2 shows mixture proportion details of geopolymer paste.

Table 2. Mixture proportion details

\begin{tabular}{|c|c|c|c|c|c|c|}
\hline \multirow{2}{*}{ Code } & $\begin{array}{c}\text { MK } \\
\% \\
\text { by } \\
\text { mass }\end{array}$ & Num & & \multicolumn{2}{|c|}{ Precursor } & \multicolumn{2}{|c|}{ Alkaline activator } \\
\cline { 4 - 7 } & $(\mathrm{pcs})$ & FA $)$ & $\begin{array}{c}\text { FA } \\
(\mathrm{gr}\end{array}$ & $\mathrm{NaOH}$ & $\begin{array}{c}\mathrm{Na} 2 \mathrm{SiO} \\
3\end{array}$ \\
\hline MK 1 & $0 \%$ & 6 & 0 & $\begin{array}{c}10 \\
9\end{array}$ & 24 & 48 \\
\hline MK 2 & $25 \%$ & 6 & 27 & 81 & 24 & 48 \\
\hline MK 3 & $50 \%$ & 6 & 54 & 54 & 24 & 48 \\
\hline MK 4 & $75 \%$ & 6 & 81 & 27 & 24 & 48 \\
\hline MK 5 & $\begin{array}{c}100 \\
\%\end{array}$ & 6 & 109 & 0 & 24 & 48 \\
\hline
\end{tabular}

\subsection{Laboratory test}

Compressive strength test was performed according to ASTM C39-03 guidelines. Test was experienced on geopolymer paste with the age of 7, 14, 21 and 28 days using Universal Testing Machines (UTM) at Laboratory Structure of ITS Surabaya. The testing result was evaluated by taking average value from 6 specimens.

Setting time test was referred to ASTM C 191-92. Hence, porosity test was conducted in geopolymer paste with the age of 28 days as referred to AFNOR NF B 49104. Documentation of setting time and compressive strength test were presented at figure 2 .

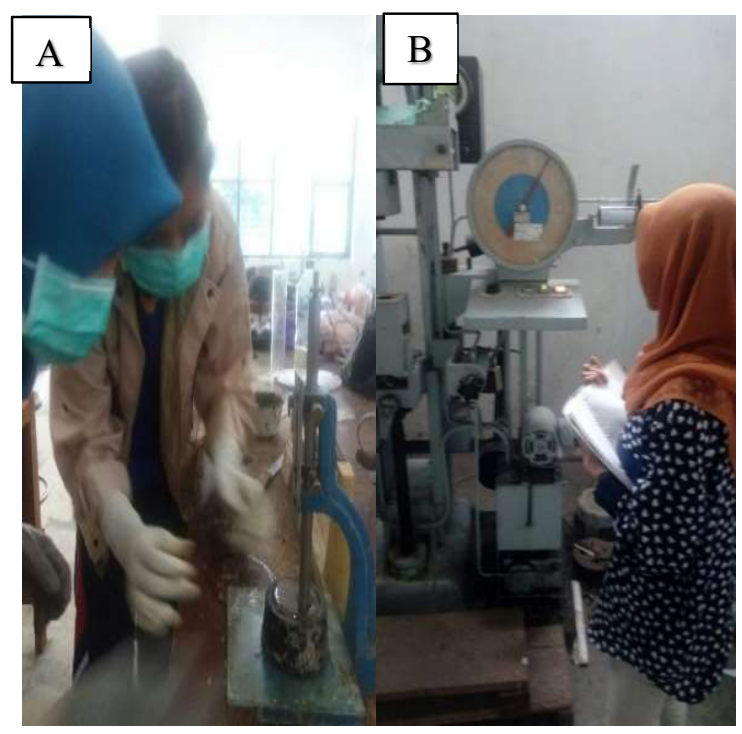

Fig. 2.(a) Setting Time Test, (b) Compressive Strength Test 


\subsection{Curing}

Immediately after moulding, specimens were covered with plastic cover and left in room temperature until testing date to reduce evaporation. Picture of several paste specimens was presented at figure 3 .

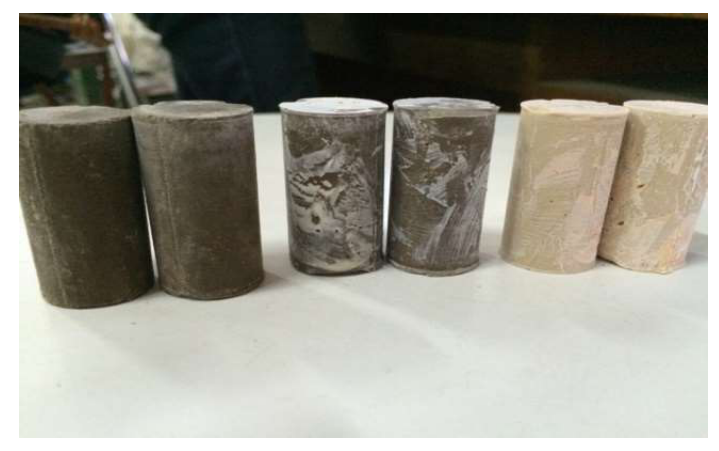

Fig. 3. Geopolymer paste specimens

\section{Result and discussion}

\subsection{Density}

The density test results of geopolymer paste are presented on table 3. Based on data presented at table 3 , it can be seen that all samples have ranged of density between 1.8 to $2.1 \mathrm{gr} / \mathrm{cm}^{3}$. Hence, it is proven that metakaolin levels affect the density of geopolymer paste. The higher MK content in the mixture, the lower density of geopolymer paste produced.

The low density of paste with low MK content probably caused by the high amount of open pore occurred [7]. In addition, metakaolin which has similar character with clay experience easy expand and shrinkage when reacts with water. So that, open pore occurred in sample with high content of MK become higher than others [8]. Moreover, this condition will be discussed further in this paper.

Table 3. Density test result

\begin{tabular}{|c|c|}
\hline Sample code & Density $\left(\mathbf{g r} / \mathbf{c m}^{\mathbf{3}}\right)$ \\
\hline MK 1 & 2.10 \\
\hline MK 2 & 2.07 \\
\hline MK 3 & 2.07 \\
\hline MK 4 & 1.9 \\
\hline MK 5 & 1.8 \\
\hline
\end{tabular}

\subsection{Compressive strength}

The compressive strength test result of geopolymer paste was presented in Table 4. All specimens experienced optimum compressive strength at the age of 28 days. Compressive strength of all the samples at 28 days was in the range of 4.73 to $38.32 \mathrm{MPa}$. Sample MK 2 which has metakaolin content of $25 \%$ owned highest compressive strength among the others. It can be concluded that the addition of $25 \%$ of $\mathrm{MK}$ to the mix provides optimum compressive strength results. The compressive strength experienced to decrease in paste with MK content of more than $25 \%$. These results has a good agreement with previous studies stated that the level of class $\mathrm{N}$ pozzolan optimum in geopolymer paste mixture is 25 to $50 \%$ [9].

Table 4. Compressive strength test result

\begin{tabular}{|c|c|c|c|c|}
\hline \multirow{2}{*}{$\begin{array}{c}\text { Sample } \\
\text { code }\end{array}$} & \multicolumn{4}{|c|}{ Compressive strength of each age (MPa) } \\
\cline { 2 - 5 } & $\mathbf{7}$ days & 14 days & 21 days & 28 days \\
\hline MK 1 & 5.97 & 24.23 & 30.64 & 38.32 \\
\hline MK 2 & 2.09 & 25.11 & 30.72 & 40.03 \\
\hline MK 3 & 11.22 & 20.21 & 24.23 & 27.65 \\
\hline MK 4 & 3.14 & 8.60 & 9.99 & 12.57 \\
\hline MK 5 & 0.68 & 1.51 & 2.23 & 4.73 \\
\hline
\end{tabular}

The relationship between the compressive strength of geopolymer paste at each age is presented in Figure 4. According to the graph presented in Figure 4, it can be seen that the samples which contained more than $25 \%$ MK was experienced to slow react, which is indicated by the slow increasing of compressive strength at each testing age. Paste with a level MK content of $25 \%$ and paste without MK content has significant increasing of compressive strength at early age and has not showed stability compressive strength at the age of 28 days. Reactivity of Mk was presumable as the causes of slow reacting of sample contained MK levels over $25 \%$. The previous study by Van Jaarveld mentions that the reactivity of the precursor has a great influence in the mechanical properties of geopolymer paste [10]. The less reactive of MK possible occur because the imperfections combustion process of kaolin into metakaolin. Previous research by Triani states that the temperature and the combustion quality are very essential in the activation process of kaolin [11].

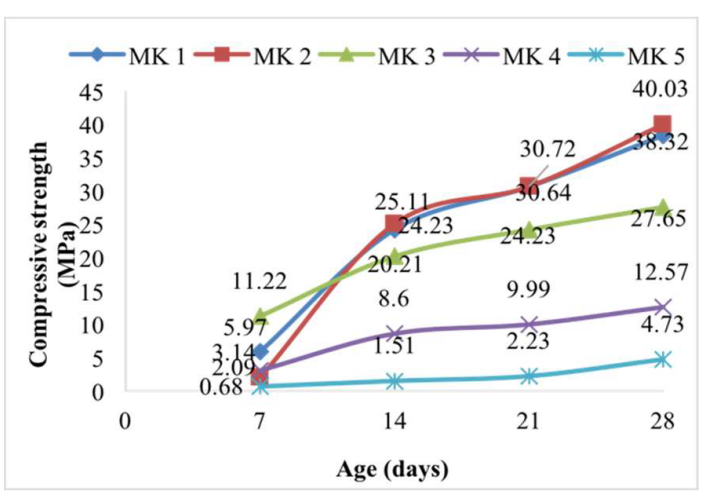

Fig. 4. Compressive strength of geopolymer paste at different age

\subsection{Setting time}

Setting time test result was presented at table 5. Initial and final setting time result of all variants has range value from 165 minutes to 2 days. The shortest setting time was owned by sample MK1 which contain $0 \%$ MK, while the longest setting time was owned by sample MK 5 which 
contain $100 \%$ MK. Hence, it can be concluded that MK contained in the mixture has directly proportional relationship with setting time of its geopolimer fresh paste.

Table 5. Setting time test result

\begin{tabular}{|c|c|c|}
\hline Sample Code & $\begin{array}{c}\text { Initial setting } \\
\text { time } \\
\text { (Minutes) }\end{array}$ & $\begin{array}{c}\text { Final setting } \\
\text { time } \\
\text { (Minutes) }\end{array}$ \\
\hline MK 1 & 165 & 240 \\
\hline MK 2 & 240 & 345 \\
\hline MK 3 & 720 & 960 \\
\hline MK 4 & 1080 & 1500 \\
\hline MK 5 & \multicolumn{2}{|c|}{ more than 2 days } \\
\hline
\end{tabular}

The higher the levels of metakaolin in the mixture, the longer setting time of fresh geopolymer paste occured. This is consistent with previous research by Risdanareni which states that the addition of pozzalan class $\mathrm{N}$ to the geopolymer paste mixture can prolong setting time [12]. Additionally $\mathrm{CaO}$ content in the mixture also affect the value of setting time. Fly ash has higher a $\mathrm{CaO}$ content compared to metakaolin so that a mixture that containing a lot of metakaolin will have fewer $\mathrm{CaO}$ content that deliver long setting time [13].

\subsection{Porosity}

The amount of open and close pore of geopolymer paste was illustrated in figure 2. Open pore is a pore that is permeable so that it can be penetrated by water and air, while the close pore is impermeable so that water and air cannot pass [14].

Referring from data displayed in figure 5 , it can be seen than sample MK 2 owned lowest open pore number and highest close pore number. Sample with MK content more that $25 \%$ experienced high open pore and low close pore. The higher MK content in the mixture the higher open pore occurred. The characteristic of metakaolin presumed cause this condition.

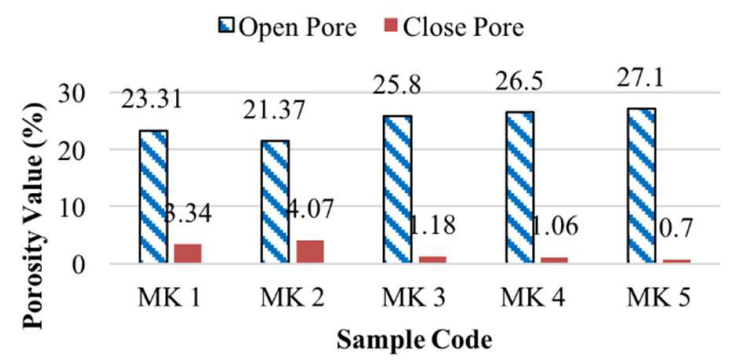

Fig 5. Porosity test result

The result of open pore test is closely associated with the compressive strength and density test result. The test results of open pore, compressive strength and density of geopolymer paste was mentioned in table 6 . Based on data presented at table 6 , it can be seen that sample which has high number of open pore would have a low compressive strength and density value. So it can be concluded that the number of open pore is inversely proportional to the compressive strength and density of geopolymer paste. This is consistent with previous studies which stated that increasing the number of open pore will decrease the compressive strength and density of geopolymer paste [14].

Table 6. Relationship between mechanical and physical properties test

\begin{tabular}{|c|c|c|c|}
\hline $\begin{array}{l}\text { Sample } \\
\text { Code }\end{array}$ & $\begin{array}{c}\text { Open } \\
\text { pore }(\%)\end{array}$ & $\begin{array}{c}\text { Compressive strength } \\
\text { (MPa) }\end{array}$ & $\begin{array}{l}\text { Density } \\
\left(\mathrm{gr} / \mathrm{cm}^{3}\right)\end{array}$ \\
\hline MK 1 & 23.31 & 38.32 & 2,109 \\
\hline MK2 & 21.37 & 40.03 & 2,069 \\
\hline MK3 & 25.8 & 27.65 & 2,069 \\
\hline MK4 & 26.5 & 12.57 & 1,870 \\
\hline MK5 & 27.1 & 4.73 & 1,830 \\
\hline
\end{tabular}

\subsection{Microstructure of Precursor}

SEM (Scanning Electron Microscopy) test was conducted in order to investigated morphology of fly ash and metakaolin. Microstructure test result of fly ash and metakolin was presented at figure 6. Previous research by Tajunnisa stated that microstructure of precursor influences mechanical properties of geopolymer paste. SEM test result can be used to predict mechanical and physical characteristic of geopolymer paste. [15] Fernadez was also stated that particle size and particle distance play an important role in developing properties of geopolymer binder. [7] Particle distance play an important role in developing mechanical properties of geopolimer paste because the geopolyerization only occur at surface area of precursor. [16] So it can be concluded that, the larger particle distance of precursor, the lower mechanical properties of geopolymer paste occur.

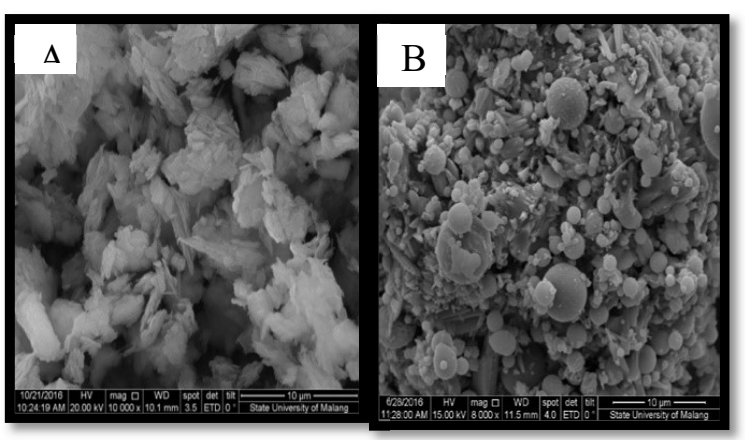

Fig 6. (a) microstructure of metakaolin, (b) microstructure of fly ash

Refer to figure displayed at figure 6 it can be seen that fly ash has spherical shape while metakaolin has irregular shape (bulky). Due to its irregular shape, metakaolin has large particle distance compared to fly ash which has homogenous spherical shape. This result has a good agreement with compressive strength result of geopolymer pasta. The optimum metakaolin content in the mixture is $25 \%$ and compressive strength is experienced to decrease with increasing of metakaolin content. Hence 
it can be concluded that metakolin which has bulky shape and has large particle distance can decrease the mechanical properties of geopolimer paste.

\section{Conclusion}

The result evidenced that metakaolin content as fly ash replacement has a great influence in developing mechanical and physical properties of geopolymer paste such as density, compressive strength, setting time and porosity. The high level of metakaolin content will decrease the compressive strength and density of geopolymer paste. However, increasing metakaolin content will deliver longer setting time and higher open pore. Microstructure of precursor was also influence the physical and mechanical properties of geopolymer paste. Precursor which has short distance particle and homogenous shape will deliver high compressive strength of pasta produced. Based on several testing on investigating mechanical and physical properties of geopolymer paste in this research, it can be concluded that replacing $25 \%$ of fly ash with metakaolin proved to give better mechanical and physical properties.

The authors gratefully acknowledge The Directorate General for Higher Education, Ministry of Research, Technology and Higher Education, Indonesia, who provided the research grant through the 'Penelitian Kerjasama Antar Perguruan Tinggi (PEKERTI)' scheme in 2016.

\section{References}

1. C.A Hendriks, Proceedings of the 4th International Conference on Greenhouse Gas Control Technologies, Interlaken, Austria, Aug. 30-Sept. 2 , IEA GHG R\&D Programme, UK( 1998)
2. E. Gartner, Cement and Concrete Research, 34, 1489-1498 (2004)

3. Davidovits, Journal of Thermal Analysis Vol. 37, (1991)

4. D. Hardjito, Studies on Fly Ash-Based Geopolymer Concrete, Curtin Univ of Technology, (2005)

5. R. Nurwidayati, M.B. Ulum, J.J. Ekaputri, Triwulan, P. Suprobo, Materials Science Forum, Vol. 841, pp 118-125, (2016)

6. J. Ekaputri, Triwulan, Jurnal Teknik Sipil ITB Vol 20 No.1 (2013)

7. Ferna'ndez-Jime'nez, Palomo, Characterisation of Fly ashes Potential Reactivity as Alkaline Cement, Fuel Vol. 82 pp 2259-226, (2003)

8. F. Slaty, H. Khoury, J. Wastriels, H. Rahier, Characterization of Alkali Activated Kaolinitic Clay, Applied Clay Science, (2003)

9. P. Risdanareni, A. Karjanto, J.J. Ekaputri, P. Puspitasari, F. Khakim, Material science Forum Vol. 857, (2016)

10. V. Jaarsveld, J. Van Deventer and G. Lukey, Materials Letters, vol. 57, p. 1272-1280, (2003)

11. D.N.D Triani, J.J Ekaputri, Triwulan, S. Hardono, T.E Susanto, Material Science Forum Vol. 841 pp 111-117, (2016)

12. P. Risdanareni, A. Karjanto, F. Khakim, Material science Forum Vol. 841, (2015)

13. Antoni, S.W. Wijaya, D. Hardjito, Material Science Forum Vol 841, (2015)

14. P. Risdanareni, J.J Ekaputri, M.M.A.B Abdullah, Applied Mechanics and Materials Vol. 754-755, (2015)

15. Y. Tajunnisa, M. Sugimoto, T. Sato, J.J. Ekaputri, M.Shigeishi, International Conference and Exhibition of Structural Faults and Repair 2016, Edinburg, 17th-19th May, (2016)

16. J. Duchesne, L. Duong, T. Bostrom, R. Frost, Waste Biomass Valor, 1:367-377,(2010) 